\title{
On the Arts
}

\section{THE MODELS OF PICASSO'S ROSE PERIOD: THE FAMILY OF SALTIMBANQUES}

\author{
Harold P. Blum and Elsa J. Blum
}

\begin{abstract}
The word "model" in this context has a variety of meanings. The concept of "model" encompasses the external person who is represented by the artist, as well as the internal, conscious and unconscious, past and present mental representations of other individuals and the work of other artists. In all of these meanings, the relationships of artist and model have been quite specific to the artist under consideration and the historical-cultural period. For Picasso, the relationship of artist and model was particularly intense, reflecting myriad aspects of his personality and artistic development. The theme of artist and model was the subject of many of his paintings and graphic works. We focus particularly on his use of harlequins, saltimbanques, and circus performers during his blue and rose periods. The change in predominant models and moods between periods is noted. Among the issues considered is the relevance of these models in this particular period. Why were they especially salient objects for identification and for his artistic identity? Identification with the model may represent or be linked to earlier identifications of adolescence and childhood. We discuss the implications of these portrayals for his object relationships and the magical power, possession, and control in the development of his art. The painting "The Family of Saltimbanques," his most ambitious work to date, the integration and culmination of this theme during this period, is of particular interest.
\end{abstract}

KEY WORDS: Picasso; artist; models; Saltimbanques; identity; identification.

DOI:10.1057/palgrave.ajp.3350023

\section{INTRODUCTION}

Some salient psychoanalytic perspectives on the relationship of artist and model will be explored in this paper. During the "rose" period, from about the latter half of 1904 through 1905, Picasso drew, etched, and painted many figures and small groups of saltimbanques, harlequins, and jesters. These circus types were the main subjects of his rose period art. Using

Harold P. Blum, M.D., Clinical Professor of Psychiatry, NYU School of Medicine; Executive Director, Sigmund Freud Archives; Training and Supervising Psychoanalyst, NYU Psychoanalytic Institute.

Address correspondence to Elsa J. Blum, 23 The Hemlocks, Roslyn, NY 11576-1721; e-mail: elsablum@cs.com 
images of these performers, Picasso's interrelated ouevre on this theme culminated in his remarkable oil painting, "The Family of Saltimbanques" (1905) (National Gallery of Art, Washington, DC) (Figure 1).

We will consider the meanings of these performers as models during this period and more specifically, the models for the painting "The Family of Saltimbanques." In ordinarily parlance, the model that is represented in a painting or drawing is an external model, a person, or an inanimate object.

Whether or not the artist has or has not worked directly from an external model, the artistic production may incorporate the fantasy distortions of internal models and unconscious representations within the psyche of the artist. The external model, modified by the rich imagination of the artist can represent aspects of the self and other internal object representations, or a composite representation that incorporates aspects of the real model.

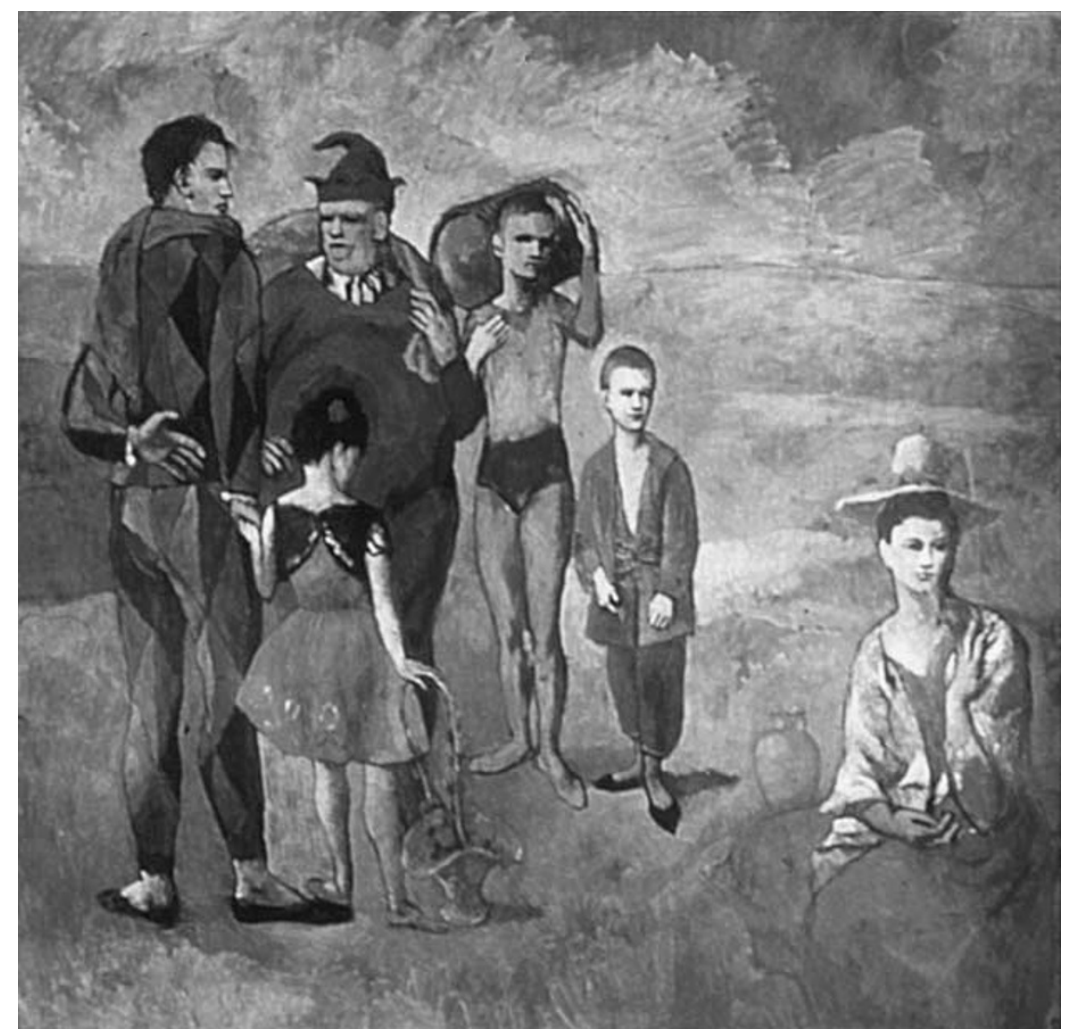

Figure 1: "The Family of Saltimbanques". 
The quality of the relationship between artist and model may range from relatively dispassionate, common in the case of commissioned portraits, to extremely intense when the model is an essential person in the real life or fantasy of the artist. A model may be a relative, friend, or stranger, and may be or become a spouse or lover. The model may be muse or cocreator, facilitating or inhibiting the creative process. Both consciously and unconsciously, the external object may serve as a model for identification, artistic communication, and sublimation. The artist may be the conscious external model, as in the self-portrait, as well as the unconscious internal model in other works. Michelangelo noted that all of his work had aspects of selfportraiture, and Leonardo warned the aspiring artist of the danger of always painting himself.

As in a dream, the image in a work of art may be a composite, a condensation of self and object representations, or a collective object such as a family or social group. The model may represent all developmental levels from merger to highly differentiated and rather realistic self and object representations. The model may be created, destroyed, and recreated in the art work. The model may also learn from the artist, identify with the artist, and become an artist, as happened in the artistic development of Suzanne Valadon. (Valadon modeled for Degas, Lautrec, Renoir, and was the mother of Maurice Utrillo.) In one of Picasso's playful graphics, the nude model is the artist, and in another the artist is a monkey (Leiris, 1973). Present in all art, voyeuristic-exhibitionistic issues are inherent in the relationship of artist and model as well as the relationships of both artist and model to the real and/or fantasied viewer. The spectator may also be identified with the model and/or the artist.

\section{RELATIONSHIP OF ARTIST AND MODEL}

The choice and meaning of the model or models is psychologically significant, differs for each artist and model, and may change over time. An artist may have a special relationship with a model prior to or beginning with the work of art. Picasso spontaneously asked Gertrude Stein to pose for a portrait soon after they first met, after she had become a patron. After numerous sittings, Picasso was still not satisfied and completed the portrait (Metropolitan Museum of Art, New York) in her absence (1906). When friends exclaimed that Gertrude Stein did not look like the portrait, Picasso purportedly stated "she will." Clearly, the model need not be physically present.

Leonardo is reported to have had the Mona Lisa (The Louvre, Paris) pose for her portrait over a four-year period, during which he hired entertainers to keep her pleased and involved. During such a lengthy period, the 
original relationship between artist and model must have changed and further developed. The Mona Lisa very likely unconsciously represented a mother figure with whom he was identified (Blum, 2001). Magically possessing her through painting her, Leonardo actually never parted from this special work. The relationship to the model may influence the style of the artist as apparently occurred in the case of Picasso. The psychoanalytic interpretation of art traditionally relates the life and work of the artist; the art or text, however, may also be interpreted independent of considerations of the artist or author. While the artists' traumas and unconscious conflicts influence his/her art, artistic gifts also depend on intact aspects of the personality, relatively autonomous from conflict, trauma, and regression. An artist's particular style emerges from past conflicts and traumas, but also from artistic considerations, challenges, and esthetic choices. Picasso's numerous changes of style during his long life were codetermined by his unconscious conflicts and the vicissitudes of his artistic temperament, endowment, and evolution. His remarkably flexible and fluid artistic capacities and wide choice of models contributed to his creative innovations of style and form, and are not indicative of personal identity diffusion.

\section{TRANSITION TO PARIS AND THE ROSE PERIOD}

Picasso left Spain for Paris in 1901, at 19, a voyage of separation and stimulating new experience at the end of adolescence. By 1904, Picasso himself had emerged as a more rooted person, becoming established in his new life in Paris, even while nostalgic for his former Spanish life and family. Picasso needed to separate and individuate (Mahler, Pine, and Bergman, 1975), and after four round trips between Spain and Paris, he settled in Paris. His return home and departures at the end of adolescence were echoed in his later life and art. He tended to alternate between closeness and distance. Picasso was a seducer and despot attempting to possess and control the other, including his models.

In Paris, Picasso learned a new language, made new friends, and developed a romantic relationship with an attractive live-in mistress, Fernande Olivier. At the same time, he was developing a new pictorial language of artistic expression as well. He was now surrounded by a group of French writers and poets, who along with Fernande, constituted the "Bande a Picasso." All became models for Picasso. This new French group replaced the "Tertulia," the typical Spanish group of men who spent their free time socializing together. The group had its own argot, entertained Picasso and each other, attended the circus and theater together, etc. Completing a metamorphosis from late adolescence to adulthood, his psychological internal transformation paralleled his artistic change from the despondent 
blue period of loss and depression to the revitalized self and reconstituted family of the rose period. It is of interest that Picasso's first known lover, when he was an adolescent, was a circus rider, Rosa. Reminiscences of this equestrienne perhaps enhanced Picasso's interest in the circus, to which he was practically addicted, in his early years in Paris. Rosa may also have been a hidden reference in Picasso's inclusion of a horse race in the background of a preliminary version of "The Saltimbanques." Life now had a rosier quality. Admired by his gifted devoted poet laureates, Picasso was on the threshold of recognition by the first collectors of his work. Picasso's very appreciative and supportive new family and a mistress (Fernande Olivier) whom he managed to keep, despite her tendencies to wander, were sustaining and stabilizing objects. Settling into Paris with Fernande and friends, he began to explore radically new pathways in his art. His surrogate family esteemed his original art, contributing to his narcissistic equilibrium and gratification. This was needed because of Picasso's fragile self-esteem and to protect his artistic identity and creativity in a social surround, which did not yet fully recognize and respect his accomplishments. Although he tended to change the style of his art and clothes, as well as quarters, with each new lover, there were always multiple determinants to his stylistic changes. While his relationship with Fernande, (1904-1911), his model for numerous works, began with the rose period, it continued into his cubist period. During these fateful years, Picasso first met Matisse and formed a virtual artistic twinship with Braque.

Picasso met Apollinaire at the end of 1904, and they instantly became intimate friends. They intuitively recognized each other as a great artist and a great poet, and Apollinaire, in his writings as an art critic, contributed to Picasso's burgeoning artistic stature. Max Jacob, homosexual and Jewish, had become Picasso's closest companion of the Paris blue period, supplanting his Spanish friends. He served as house poet, clown, and jester. He would act, joke, and sing, as well as recite French poetry and classical literature. He had also become Picasso's French instructor, facilitating Picasso's adaptation to his new life situation. Jacob now had to compete with this brilliant new heterosexual poet and idealized friend, a model of rivalry for the later members of Picasso's entourage. Andre Salmon also joined the group in 1904, and as a writer, along with Fernande Olivier (1965), produced significant memoirs of this important period in the history of art. Each member of the group modeled for a Picasso portrait. Avant-garde and nonconformists, the group itself, a collective object, became a model of artistic innovation and development, facilitating the transition to the rose period.

Picasso's self-confidence had flagged at the dawn of the blue period after he painted a brash self-portrait labeled "Yo Picasso." This was a determined 
self-assertive, even cocky self-portrait as an artist, quickly followed by a blue somber self-portrait also labeled "Yo." The third self-portrait in this sequence, about six months later, depicts a dour depressive, overtly disappointed unrecognized artist. By the time of the rose period, he was more self-assured and self-confident, as he looked at himself and the world through rose-colored glasses. He had only relatively assimilated and mastered the separation from his Spanish family, reflected in the melancholy "blue period." This late adolescent separation and migration also seemed to be associated with the losses, through death from diphtheria of his sister, Conchita and through the suicide of his close friend, Casagemas. Conchita had died at age six, when Picasso was 14. Casagemas had been living in Barcelona and Paris with the 19-year-old Picasso; his death (February 17, 1901) occurred during Picasso's late adolescent separation from his family and revived earlier losses. Picasso reconstituted a new life as he moved into young adulthood. The misery expressed in the blue period paintings, reflecting the traumata of separation, loss, and painful separateness, was behind him, as he moved in new directions (Rose, 1996).

\section{PICASSO'S MODELS}

In addition to the meanings discussed above, the term "model" in art may also refer to the conscious or unconscious influence of other artists and their work, contributing frequently to the shaping of the artist's identity as an artist. We will focus particularly on Picasso's representions of saltimbanques, harlequins, and circus figures, particularly in his painting "The Family of Saltimbanques." In these works, Picasso modeled himself on past masters who had painted the same theme, for example, Cezanne, Manet, Seurat, and Toulouse-Lautrec. Infrequently using paid models, Picasso represented a wide variety of models: lovers, family members, friends, other painters, poets, acquaintances, theatrical performers, etc., often working from memory. During the "Blue" period, he painted beggars, prostitutes, jail inmates, and other depressed, haggard, hungry social outcasts. Although Picasso made at least two paintings of harlequins prior to the "rose" period, the theme of harlequins, saltimbanques, and circus performers became dominant at this time (Figure 2).

In addition to the work of earlier artists, Picasso was also influenced by the extensive literature on saltimbanques and harlequins as well as by attending their performances at the theater, opera, and the circus. The saltimbanques appeared in the poetry of Rimbaud, Verlaine, and later Rilke, Jacob, and Apollinaire. Max Jacob, his close friend, himself a clown, actor, singer, and poet for Picasso and his friends, enticed Picasso to the opera, including I Pagliacci and La Boheme, which depicted typical harlequin type 

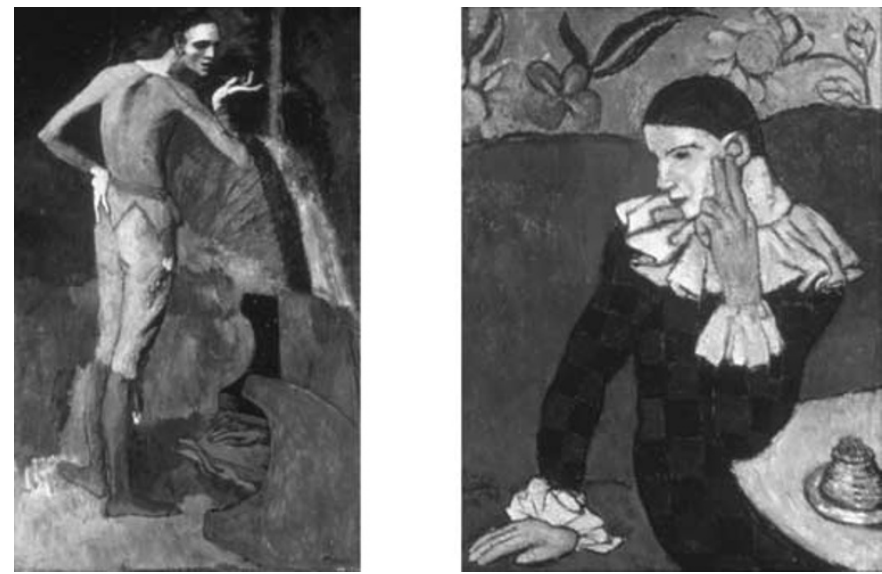

Figure 2: "The Actor", "The Harlequin".

figures of Pierrot and Columbine, as well poor, marginal bohemians. During this period, Picasso and his little band of poet companions attended the circus frequently, often several times a week. This perhaps was in part a substitute for his beloved theater, since his initially limited grasp of the French language impeded his readily following the theatrical dialogue. Picasso regularly interacted with these circus characters, sometimes talking to the acrobats and clowns for hours. They became models with their characteristic costumes, but represented beneath their conventional costumes was the artist himself and his intimate object relationships. Picasso's life and work were profoundly intertwined (Gedo, 1980), and he compared his paintings to a personal diary, but his art also profoundly influenced his personal life and relationships.

After the rose period works of 1904-1905, Picasso occasionally returned to portraying harlequins and saltimbanques. While these types were differentiated in previous centuries, their traditional differences had tended to disappear and Picasso used the figures rather interchangeably. Nomadic actors had portrayed harlequins in the town squares of Europe for several centuries. They usually enacted comic entertaining roles in stereotypical romances. The saltimbanques were players and acrobats. Their name derived from jumping for coins, which were soon associated with the banque. They could perform extraordinary feats, sometimes at great personal risk. The saltimbanques were also regarded, since their medieval origins as magicians, and sometimes as mountebanks. Colorful, marginal characters, both harlequins and saltimbanques were connected with the circus, and both 
had specific costumes. The harlequins typically wore lozenge-patterned outfits with bright colors or occasionally a black and white pattern, with or without a cocked hat. The saltimbanques dressed in rose costumes, often with large ruffles. The harlequin couple most often depicted was Pierrot with his female counterpart, Pierrette or Columbine. Pierrot wore a white costume with loose sleeves and Columbine usually wore a low-cut tiered gown. Identified with harlequins and with the circus, the saltimbanques represented the folly and pathos of the human condition (Reff, 1980). The saltimbanques were eternal wanderers, vagabonds, and vagrants, not belonging to any particular place; they lacked roots, social status, and personal as well as national identity. While not considered misfits and outcasts, they lived on the fringe of society and literally often on the outskirts of the towns in which they entertained.

The theme of the saltimbanque with its long tradition in European art and literature became a ready symbol and model for the artist. As players, and theatrical performers, the saltimbanques and clowns represented the artist at play. Picasso could regress to a child at play, weaving regressive and progressive elements together in his art. Picasso's "pretend play," realistic perception, and affective resonance were interwoven in his art. Playful innovation was a feature of his creativity (Winnicott, 1966), providing escape and recreation in his personal life.

No longer dependent on or supported by his family and a familiar culture and language, Picasso had to find his own way and his own artistic identity, style, and means of support. For Picasso, although the saltimbanques were marginal and could represent alienation and loneliness, these figures of the "rose" period, nevertheless, convey a lighter and brighter mood than the defeated, despondent persons of the blue period. The saltimbanques, with their special skills and tricks, replaced the often pathetic, helpless models Picasso painted during the blue period. The subsequent rose color gives warmth and light, with hints of a more cheerful existence. The works of the rose period convey a bitter-sweet relatedness to the external world of the spectator. The figures make and break contact with each other. In some paintings (such as "The Saltimbanques"), paradoxically the figures touch, sometimes sharing their body boundary, but look away from each other and appear to be inwardly preoccupied and alienated.

Picasso's identification with these models was undoubtedly multidetermined. Always intrigued by masks and the masquerade of the theater, he later created designs for ballets. While shaving, he would pretend he was a white-faced clown (Gilot, 1964). Aspects of his inner "true self" were concealed from himself and his love objects, appearing in various unconscious disguised forms in his art. He, too, loved to exhibit, to symbolically perform for an audience, to attempt risky daring artistic feats. Although he 
did many sketches of these performer-models in action, performing in public, in most paintings they are offstage, in somewhat static poses. They are frequently portrayed with their families, in private intimate scenes. Picasso depicts the person behind the theatrical façade, the clown when he is not laughing. Unlike Seurat's circus figures, swinging through the air, Picasso's are often in repose. He identifies with both the performer and the person inside the costume, under the mask... and with the performance arts. (circus, bullfight, theater, etc.) In this masquerade, Picasso is voyeur and exhibitionist, artist, model, and spectator. Significantly, his first wife was a ballerina.

\section{THE FAMILY OF SALTIMBANQUES}

We will now focus on a very renowned work Picasso painted in 1905, at age 24, "The Family of Saltimbanques." Picasso's many Saltimbanque drawings and water colors were celebrated in poems by Apollinaire and Rilke. The noncommissioned "The Family of Saltimbanques" was the largest painting Picasso had done up to that time. X-rays indicate that it was worked over in five stages during nine months, suggesting both an intense investment and conflict about the work. This enigmatic painting continues to evoke a sense of mystery and invite contemplation and varied interpretation. While Picasso usually dated his art, he rarely named the work. This painting was originally untitled; its title was derived from the content.

The group of saltimbanques is arranged against an empty background, pale tan, with a cloudy blue sky. Shades of rose and blue predominate, as in other "rose period" works. The bareness of its background almost suggests the blank canvas, ready for future innovation. Was this a holding environment and transitional space for playful exploration, and nascent creativity (Winnicott, 1966). The figures are motionless, fixed in space and time, against their essentially empty, softly colored, subdued background. The transient saltimbanques and harlequins attain permanence in their immobility. Perhaps they represent a compromise formation, expressing and defending against feelings of separation, alienation, and death. The group stands together, but apart from the world. An extant work preceding "The Family of Saltimbanques" includes a horse race in the upper right, reminiscent of those painted by Degas or Toulouse-Lautrec. In contrast to the racehorses, however, as in the final version, the performers are not in active motion.

Who were the models for "The Family of Saltimbanques?" While cloaked as saltimbanques, we can view the figures as representing not only saltimbanques, but members of Picasso's "Bande a Picasso," members of his family of origin, and perhaps Picasso himself at various ages. Precursors of 
the figures in "The Family of Saltimbanques" were drawn and painted many times in early works that can be characterized both as separate and as preparatory. Eight "saltimbanques" were exhibited in a Paris gallery in February 1905. Integrating these preliminary figures, "The Family of Saltimbanques" exemplifies Picasso's mastery of this style and subject. In both this and in "Au Lapin Agile," another major "rose period" painting, also completed in 1905, Picasso himself appears thinly disguised as a harlequin-saltimbanque, standing tall and erect, confirming in these self-portraits his identification with his saltimbanque models. In "The Family of Saltimbanques," the figures are placed from left to right in a receding order of height. Picasso is at the extreme left, larger than life, in a lozenge-patterned harlequin costume. In this painting, he is the tallest, perhaps in his art compensating for his short physical stature. He stands back to the viewer, head in profile, with one hand displayed prominently behind his back. He holds the hand of a young girl, who in turn grasps a basket of flowers, which rests on the ground. The male adjacent to Picasso is a heavy-set man, dressed in pink, with the corpulent build of Apollinaire. This figure has also been identified as a muscular circus performer, Tio Pepe. Apollinaire is powerful, but it is Picasso who is the leader, harlequin thrice great, as Apollinaire poetically referred to him. Picasso is not only the leader of his band of poet companions, but is planning to take the lead in the wider world of art.

The figure immediately to the right of Apollinaire, resembling Andre Salmon wears only a pair of briefs and carries a cylindrical bundle, apparently a drum, on his left shoulder. The youth's hair is cropped, as was Picasso's in childhood, to prevent lice. His near nudity contributes to the sense of mystery in the painting. This figure may also be another disguised representation of Picasso, described as often scantily clad in his humble, disordered apartment with Fernande. In a reversal of the nude pose, the artist can also feel exposed before the model who is a real or potential critic who has witnessed the creation of the work of art.

The shortest male figure next down the line of receding stature, most likely represents Max Jacob. The woman off to the extreme right of the picture presumably represents Fernande, in a Mallorcan costume with a pitcher from southern Spain nearby. Fernande Olivier's distance from the other figures paralleled his keeping her isolated from the larger outside world, a protected and protective yet forbidden remote mother figure. Picasso was very possessive and insecure about keeping Fernande's affection. Picasso's ambivalent and conflicted relationship with his mother was also represented by his placing himself at the opposite end of the painting from the adult female figure, avoiding close or direct contact with the object of his incestuous love and ambivalent hate. The pitcher on the ground, a 
female symbol of the breast and womb, is at some distance from the woman. This may also express Picasso's feeling insufficiently nurtured by the mother figure, represented by Fernande who was childless.

In his life and art, Picasso could be alternately close and distant with his lovers/models, engaged and detached. Concerns regarding separation versus closeness are evident not only in the placing of the woman off to the side. Although the figures in the painting cluster together, isolated against their barren background, they are psychologically separated and rather remote from each other. Each male figure makes physical contact with the next, but all are emotionally apart, not facing each other and without eye contact. This is especially significant, considering Picasso's piercing gaze and the role of the eye in visual art. The faces are sober, a slight sadness in their eyes, and otherwise expressionless facial features. The line of the jester's arm becomes continuous with the line of the inside edge of Picasso's sleeve. Emotionally apart, the two are physically united as in the "Two Saltimbanques" of 1901. All the figures appear with their feet in a ballet position, with the exception of the jester and the woman. They are motionless, perhaps ready to move, but not with an ordinary gait. The jester is depicted standing on his left leg, but his right leg is enigmatically omitted. His stance is that of a person whose weight is equally distributed on two legs. In the preparatory work his right leg is also absent. Did Picasso intend to thus emphasize his own stability, stature, and power? Picasso has arrogated to himself the role of a father, leading not only the little girl and his inspired and inspiring band of poets, but also preparing to take the lead among the family of artists. Some biographical references relate the girl to an orphan adopted briefly by Picasso and Fernande, and then returned. Richardson (1991), dating the adoption as having occurred after Picasso painted "The Family of Saltimbanques," refers to the little daughter of the building concierge. In the preliminary "Charcoal Gouache" of the "Family of Saltimbanques" (Pushkin Museum, 1905), the figure of Picasso is carrying a satchel and the little girl does not have a basket of flowers. The change in the final version of "The Saltimbanques" removes the burdensome satchel, the symbol of travel, suggesting a greater sense of stability and permanence. Substituting the girl's basket of pink flowers, Picasso suggests the blossoming of artistic creativity, reflected, as well in the pink flowers on the hat of the woman. Both the woman and the girl in the saltimbanque family may represent aspects of Picasso's feminine self, often condensed within his androgynous images. The girl may also represent his deceased little sister, given new life in his art.

The otherwise homeless saltimbanques, representing the "Bande a Picasso" are together, they are a family; they can be anywhere and nowhere in particular. Yet each person is stationed in his/her definite position. 
While the landscape of the background is desolate, the overall mood is a bittersweet melancholia. Picasso's poet friends gave him encouragement and intellectual stimulation, compensating for Picasso's lack of formal education, partly a result of his childhood school phobia. These noncompetitive verbal artists recognized his soaring achievements and helped to raise his fragile self-esteem and stabilize his narcissistic equilibrium. As his new surrogate family they perhaps also assuaged his unconscious guilt over surpassing his father and leaving his family. The artistic works representing Picasso and his loved ones are composites, with many layers of meaning.

Significantly, there are two different images of saltimbanques in Picasso's rose period art with different moods and motility. In one type, generally in drawings or other graphic works, they are in motion and connected with their performing. In another type, usually in paintings, they are static, not performing, and their inner selves surface with a degree of pensive melancholy. Aggression is internalized and potentially violent passions are safely deposited in these still figures. In the final monumental painting, "The Family of Saltimbanques," Picasso, as a saltimbanque, is not on the move, nor in motion, but static. All the figures have quiet dignity, which transcends the tenuous existence of vagabonds and wanderers. The vacant space of the background, throws the figures more into relief, with more life, yet gives the painting a more abstract quality. The space may also suggest the narcissistic void that could never be filled, despite the beneficial effect of his admiring friends and increasing acceptance in the art world. His narcissism was always reflected in his object relationships, characterized by entitlement, insensitivity, and self-centeredness.

As each of the male figures in "The Family of Saltimbanques," going from right to left, is successively taller, they may be viewed as representing the artist at different ages and stages of his own development into adulthood (Gedo, 1980) and into being a mature artist. In reverse order, the figures may represent Picasso's capacity for controlled, playful regression, a facility related to his creativity. He placed the smallest figure closest to, yet separated from that of the mistress/mother figure. Picasso thus allowed himself, as a child, to be closest to the mother, and most distant from her as an adult. The larger-than-life self-portrait within "The Saltimbanques" is overtly the idealized self. But is the artist also asking "who is the real me," in a sequential series of progressive and regressive self-representations? The fantasied audience of admiring spectators is the implicit family, to whom Picasso exhibits his artistic creativity. His narcissistic and oedipal triumph, however, is at the expense of psychological closeness and intimacy in his object relations. Sexual and aggressive impulses are inhibited, as the figures are motionless without interaction. 
The hand of the artist, although placed behind his back, facing the viewer, is prominently displayed, but its position is a reversal of the forward hand required for the painting of the picture. The hand represents the creative process of the artist with its magical qualities; infantile omnipotence empowers the artist's imagination. Picasso's hand, like the immortal, disembodied hand of the prehistoric cave artist, is omnipresent in its creativity while the creator remains a dark mystery. While the prominent hand might symbolize a repressed masturbation fantasy of phallic procreation and impregnation, the hand of a great artist is especially endowed and integrated with perceptual sensitivity and artistic vision. The omnipotence of creativity is unconsciously attributed to the hand, and many artists have done studies of hands, which are a special part of their body ego and identity. The artist magically controls creation and destruction in his hands and eyes. A painting or sculpture can represent a "brain child" to be loved, neglected, or aborted. God has the whole world in his hand, as in the creation (or destruction) in God's phallic finger in Michelangelo's Sistine Chapel painting. In the prehistoric cave paintings of Peche Merle (France), there are no human figures but the hand of an extraordinary cave artist is represented, perhaps traced, on the wall. The omnipotence to which we refer here is not simply an expression of infantile narcissism but is rather enlisted in the service of artistic creativity and novel composition.

"The Family of Saltimbanques" is a complex picture, a study in artistic creativity, which Picasso has fathered. His thumb gives rise to the little girl, the fingers to the four men. In a small sketch by Picasso, each finger of his hand roughly corresponds with a figure in the "The Family of Saltimbanques" (Richardson, 1991). He has concretely represented his "handiwork."

Who are the saltimbanques from this point of view? They are successive self-representations of the artist, as well as object representations arising omnipotently from the fingers of his own hand. As a distant observer of the created character in his art, he could engage in a review of his life as an artist, as though writing a memoir. The art could be a form of attempted self-discovery and self-repair, with concurrent self-serving disguise.

In many later works Picasso overtly used other artists as "models," for example, in his more than 50 versions of Velasquez' "Las Meninas." "The Old Musician" (National Gallery of Art, Washington, DC) by Manet, an artist much admired by Picasso, may have been a model for Picasso's "The Family of Saltimbanques" (Richardson, 1991). Manet's painting invites comparison in the setting, composition, arrangement and number of the figures, their marginal social status, and the ambiguous landscape.

During the rose period, Picasso's vision may have been literally affected by the use of drugs, for example, opium and hashish. The use of opium and/or hashish may have therefore influenced Picasso's state of mind, his 
affect regulation and moods, access to fantasy, and above all, his perception, artistic vision. The drug's influence may be manifest in the distant gaze of the figures in "The Family of S'saltimbanques," and the later inflamed appearance of the "Les Demoiselles D'Avignon."

In a drug-induced delirium, Picasso imagined he had invented photography and might as well kill himself as he had nothing more to learn (Olivier, 1965). Here is Picasso's grandiose fantasy as a great creator, to be later validated in reality. The suicidal thoughts could represent both the guilt about his creativity and fear that it could reach an impasse with narcissistic mortification. His concerns with the reality of photography versus fantasy, and with self-confidence versus fear of failure are apparent.

Picasso's models were always modified in his creative imagination. Rarely utilizing paid models, he often portrayed the same models over and over, often in widely contrasting styles and media. In doing this, he may have been expressing his own overdetermined and varied attitudes toward them. He may have been attempting to immortalize the models as well as himself, frequently representing dead persons. One can see some of his later works as attempts to depict the same model from various perspectives at the same time. Picasso may also have tried to evoke different responses in the spectator, according to the perspective that the spectator adopts.

Picasso's use of psychotropic drugs (hashish, opium, and morphine) however, stopped by about 1908. Picasso's physical condition and energies were protected for his art. In addition to conjecture about the effects of drug use on his art, another more enduring idiosyncratic feature of his lifestyle may have influenced his work. Picasso actually slept a good part of the day and worked through the night until the early morning hours when others awakened. Picasso's lifestyle reversed the usual pattern of daytime work and nighttime sleep. Those who lived with him described the major effort often necessary to arouse him from an extended drowsy state, to confront the realities of the new day (Gilot, 1964). His fear of sleep may have been related to the death of his sister Conchita and guilt over death wishes toward loved ones. His hostility and unconscious death wish could result in the poetic justice and retribution of his own death.

The sleeper, sometimes with a voyeuristic observer, was the model for many works of art. Although these were sometimes clearly nocturnal dreamlike fantasy representations, in other works a vulnerable sleeper is under the watchful protection of a keen observer. The protecting parent maintains a vigil over the sleeping child; sleep could become eternal in death, but art could be immortal. In Picasso's later art, the observer protects the sleeper from the rapacious minotaur. Picasso may have used both altered states of consciousness and altered perception in his work. The masterful "The Family of Saltimbanques" may have been partially or largely painted in a poorly 
lit room. His friends viewed different stages of the painting by candlelight. The eeriness of this scene in the darkened room is tempered by the immobilization of the figures, and their being omnipotently given the immortality of art, modulating any threat of separation or loss. The often drugged and drowsy spectators viewing the acrobats through the flickering candlelight again suggests Picasso's frequent creation of the voyeurism-exhibitionism of a primal scene. Picasso's night vision, his daydreams at night, his nightmarish scenes and dreamlike condensations may be related to his sleep disturbance and artificial nocturnal light.

\section{CONCLUSION}

Picasso's "The Family of Saltimbanques" is a landmark in early 20th century art, which synthesizes what has gone before and prepares the path for what will follow. All the preparatory sketches, drawings, and paintings of saltimbanques are integrated in the final encompassing "The Saltimbanques." In the painting, he was depicting a metamorphosis from late childhood to adulthood, in life and art. The regression-progression axis is controlled, and reversible. Perhaps Picasso remained in some respects an adolescent in his artistic identity, preserving an extraordinary fluidity of identification, which facilitated creative transformation. His psychological internal transformation was paralleled by his artistic change from the despondent blue period of loss and depression to the revitalized self and reconstituted family of the rose period.

The rose-colored fantasy of "The Family of Saltimbanques" looks back to the blue period and ahead to his next monumental work, "Les Demoiselles d'Avignon" (1907). This new bordello group is very different in expression and mood from the impassive, stabilized, mildly melancholic "The Family of Saltimbanques"; nevertheless, a similar palette is retained. In this groundbreaking work, the four male saltimbanques and Fernande are replaced by another group of five, the close-up primitive group of prostitutes. Although the saltimbanques were fringe characters, the prostitutes were not socially acceptable, potentially dangerous in their appeal. They appear to be linked to Picasso's radical departure from the traditions of Western art in "Les Demoiselles d'Avignon." The alien, abstract, and, to some, grotesque figures were modeled from primitive Spanish and African art, transformed by the artist's original vision. Three have been identified by Picasso as Fernande, Marie Laurencin (Apollinaire's mistress, introduced to him by Picasso), and Max Jacob's grandmother, who was originally from Avignon (Kahnweiler, 1933). The angular shapes in the draperies, appear to be modeled after El Greco, another favorite of Picasso. After a phase of stabilizing reorganization, depicted in "The Family of Saltimbanques," 
Picasso made a daring leap into new artistic territory. The strange bordello scene, so shocking at the time, was much closer to the primitive fantasies behind the mask and façade of culture than the relatively dignified "The Family of Saltimbanques." The aggression that was suppressed and repressed in the static saltimbanque figures emerged in the tense frightening figures of the "Les Demoiselles d'Avignon." Cruelty and sadomasochism are unmasked in the fearful masks and alteration in the artist's vision. Picasso's aggression, especially toward women, so internalized in the blue period and attenuated in the rose period was now overtly expressed in his artistic production. The nightmarish quality of the painting presaged a radical alteration of the artist's vision. Aggression was primarily mobilized in the service of his separation and revolutionary divergence from the traditional forms of Western art. The saltimbanque family would be deconstructed and reconstructed anew in Picasso's personal odyssey and the created world of his art.

\section{REFERENCES}

Blum, H. (2001). Psychoanalysis and art, Freud and Leonardo. Journal of American Psychoanalytic Association, 49, 1409-1426.

Gedo, M. (1980). Picasso: Art as autobiography. Chicago: University of Chicago Press.

Gilot, F. (1964). Life with Picasso. New York: McGraw-Hill.

Kahnweiler, D. (1933) Picasso interview, December 2, 1933 published in Le Point (Souillac), XLII (October 1952) 24.

Leiris, M. (1973). The Artist and his model. In R. Penrose \& J. Golding (Eds.) Picasso in retrospect (pp. 243-262). New York: Praeger.

Mahler, M., Pine, F. \& Bergman, A. (1975). The psychological birth of the human infant. New York: Basic Books.

Olivier, F. (1965). Picasso and his friends. New York: Appleton-Century.

Reff, T. (1980). Harlequins, saltimbanques, clowns, and fools. Artforum October 1971, pp. 30-43.

Richardson, J. (1991). A life of Picasso. New York: Random House.

Rose, G. (1996). Trauma and mastery in life and art. New York: International Universities Press.

Winnicott, D. (1966). The location of cultural experience. International Journal of Psychoanalysis, 48, 368-372. 